6 - ORIGINAL ARTICLE

TRANSPLANTATION

\title{
Effects of glucose and glutamine concentrations in human dental pulp stem cells viability. An approach for cell transplantation ${ }^{1}$
}

\author{
Natasha Machado ${ }^{\mathrm{I}}$, Silvio Eduardo Duailibi ${ }^{\mathrm{II}}$, Jennifer Adriane dos Santos ${ }^{\mathrm{III}}$, Vanessa Penna ${ }^{\mathrm{III}}$, Lydia Masako Ferreira ${ }^{\mathrm{IV}}$, Monica \\ Talarico Duailibi ${ }^{\mathrm{V}}$
}

DOI: http://dx.doi.org/10.1590/S0102-8650201400160006

${ }^{I}$ MS, Postgraduate Program in Translational Surgery, Paulista School of Medicine, Federal University of Sao Paulo (EPM/UNIFESP), Brazil. Cell culture experiments; conception and design of the study; acquisition, analysis and interpretation of data; manuscript writing.

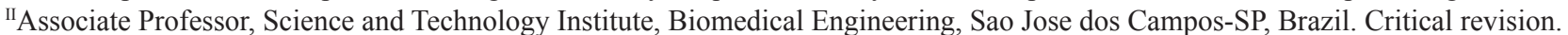

IIIMS, Postgraduate Program in Translational Surgery, EPM/UNIFESP, Sao Paulo-SP, Brazil. Interpretation of data, manuscript writing.

${ }^{\mathrm{IV}} \mathrm{PhD}$, Full Professor, Chairwoman Plastic Surgery Division, Department of Surgery, UNIFESP, Sao Paulo-SP, Brazil. Critical revision.

vAffiliate Professor, Plastic Surgery Division, Surgery Department, EPM/UNIFESP, Sao Paulo-SP, Brazil. Critical revision.

\begin{abstract}
PURPOSE: To evaluate microscopic behavior and viability of dental pulp stem cells under glucose and glutamine deprivation.

METHODS: Human tooth tissues were minced in isolated pieces and cultured until the desired cellular proliferation for experimental phases. Cells were cultured under variations of glucose and glutamine in both serum presence and absence, and then those cells were evaluated according to number and viability by MTT assay. The confocal microscopy analyzed cytoskeleton, nucleus, and mitochondria integrity.
\end{abstract}

RESULTS: A low concentration of glucose favored cellular viability and microscopic behavior; the presence of glutamine in culture medium was favorable only when associated with glucose. The cellular biological potential in culture could be preserved in serum absence if nutritional requirements are adequate.

CONCLUSION: Cell microscopic behavior and viability have demonstrated better patterns on serum-free low glucose culture medium with glutamine deprivation.

Key words: Dental Pulp. Culture Media. Glucose. Glutamine. Regenerative Medicine. 


\section{Introduction}

Human dental pulp stem cells (DPSc) have a great potential for Regenerative Medicine (RM) applications ${ }^{1,2}$. However, a preclinical phase still needs in vitro steps for cell proliferation, and well-established patterns are required to guarantee the conception of an appropriate biological material to restore human parts ${ }^{3-6}$. The in vitro nutrients importance, specially glucose and glutamine, are largely discussed in the literature ${ }^{7-11}$. In this sense, monitoring concentrations of these nutrients has become a laboratory routine ${ }^{12}$, and the culture medium industry fits these requests. Therefore, the question arises: what are the appropriate nutrient concentrations? Deregulation of glucose and glutamine metabolism and imbalance of nutrient availability could damage important biological activities like growth, genetic expression, macromolecules synthesis, purine and pirimidine formation, and energy production ${ }^{13}$. Furthermore, in vitro extracellular environment, alters the cell's natural characteristics and function ${ }^{9}$, which may impair the quality of biological material, but stem cells' nutritional requirements have not been identified yet ${ }^{11}$. Signaling pathways of apoptosis, cell's survival and growth has a close correlation with glucose and glutamine metabolic use $\mathrm{e}^{13,14}$. In order to preserve cells' natural characteristics following transplantation, and based on nutrients metabolic importance, the present study aims to evaluate microscopic behavior and viability of DPSc under glucose and glutamine different concentrations and deprivation.

\section{Methods}

\section{Cell culture}

Human tooth tissues were collected from patients $(\sim 14$ to 20 years old) scheduled for third molar extraction determined by professional dentists from public and/or private clinics, according to the Ethical Committee on Human Experimentation of UNIFESP (CEP/UNIFESP - 1493/11). Isolated human mineral structure and pulp organ tissues were placed in petri dishes containing a pre-warmed $\left(37^{\circ} \mathrm{C}\right)$ Hank's balanced salt solution (HBSS, Gibco BRL, Gaithersburg, MD, USA). Human tooth tissues were minced in isolated pieces from epithelial or mesenchymal tissues from periodontal ligament or pulp, respectively. The tissues were explanted on well-plates previously coated with Fetal Bovine Serum (FBS) (LGC Biotecnologia, São Paulo, Brazil). The explants were cultured under Dulbecco's modified Eagle medium (DMEM, Gibco BRL, Gaithersburg, MD, USA) and Ham's F12 medium (SigmaAldrich Corp, St. Louis, MO, USA) 1:1 supplemented with 5\% FBS and 50 units $/ \mathrm{ml}$ penicillin, $50 \mathrm{mg} / \mathrm{ml}$ streptomycin. The medium was replaced twice a week until cells confluence was obtained.

\section{Culture in different media}

Following proliferation of cell culture, cells were cultured in a chemically defined culture medium (DMEM, Invitrogen ${ }^{\circledR}$ Carlsbad, California). Commercially available formulas were utilized with different concentrations of Glucose and Glutamine: Low Glc (Glucose: $1.000 \mathrm{mg} / \mathrm{L}$ and Glutamine deprivation), Glc (Glucose: $4.500 \mathrm{mg} / \mathrm{L}$ and Glutamine deprivation), Gln (Glutamine: $584 \mathrm{mg} / \mathrm{L}$ and Glucose deprivation), and Glc/Gln (Glucose: $4.500 \mathrm{mg} / \mathrm{L}$ and Glutamine: $584 \mathrm{mg} / \mathrm{L}$ ). All culture media were added penicillin and streptomycin in the same conditions previously described and cells were cultured in both serum presence $(5 \%)$ and absence. All of the experiments were performed within 14 days of a previous culture.

\section{Proliferation assay and quantification of cell number}

The proliferation and number of cells were both analyzed by an automated cell counter (Countess - Invitrogen ${ }^{\circledR}$ Carlsbad, California). Trypan blue solution diluted, according to the manufacturer's instructions, was used to identify live and dead cells, and the total cells' number.

\section{Microscope image acquisition}

The evolution of cell culture in this study was conducted using an inverted optical microscope (Axiovert 40C Carl Zeiss $^{\circledR}$, Gottingen, Germany) in addition to AxioVision software (AxioVision Software ${ }^{\circledR}$ 4.1 Software - Germany).

\section{Confocal microscopy}

Cells were cultured on chambered coverglass slides throughout the 14 days of the study. Structural analyses were performed using Alexa Fluor 488 for cytoskeleton, Dapi for nucleus, and Mitotracker for mitocondria (Invitrogen, Carlsbad, California) following the manufacturer's instructions. Confocal Microscopy was then performed (LSM 510 META; Carl Zeiss, Germany).

\section{Viability assay}

The Methylthiazoltetrazolium test (MTT) was conducted to determine cellular viability. Mitochondrial activity, determined by the amount of blue crystal's formation, was read on Elisa spectrophotometer (wavelength 570nm) in 96 well-plates ${ }^{15}$. 


\section{Statistical analysis}

The analysis of variance (ANOVA), Dunnett and chisquare tests were applied to the results with a $95 \%$ confidence level. The statistical model ANOVA with interaction was used for viability analysis, fixing the culture media and FBS as interaction factors. Afterwards, multiple unilateral comparisons were accomplished using a non-parametric version of the Dunnett test.

\section{Results}

Descriptive statistics results showed that the Low
Glc culture medium promoted better patterns of viability, and Gln culture medium exhibited poorer results. In the serumsupplemented culture media, the patterns were similar, except for Low Glc medium that showed an important decrease (Figure 1).

ANOVA statistical test demonstrated an interaction between culture media and FBS, clearly showed by the crossing lines in the graph $(\mathrm{p}<0.001)$ (Figure 2).

A non-parametric version of Dunnett test demonstrated a significant superiority of cell viability in serum absence of Low Glc culture medium. Additionally, Glc and Glc/Gln serum supplemented culture media presented similar results, displayed by the lines crossing the reference central line $(p<0.001)$ (Figure 3$)$.
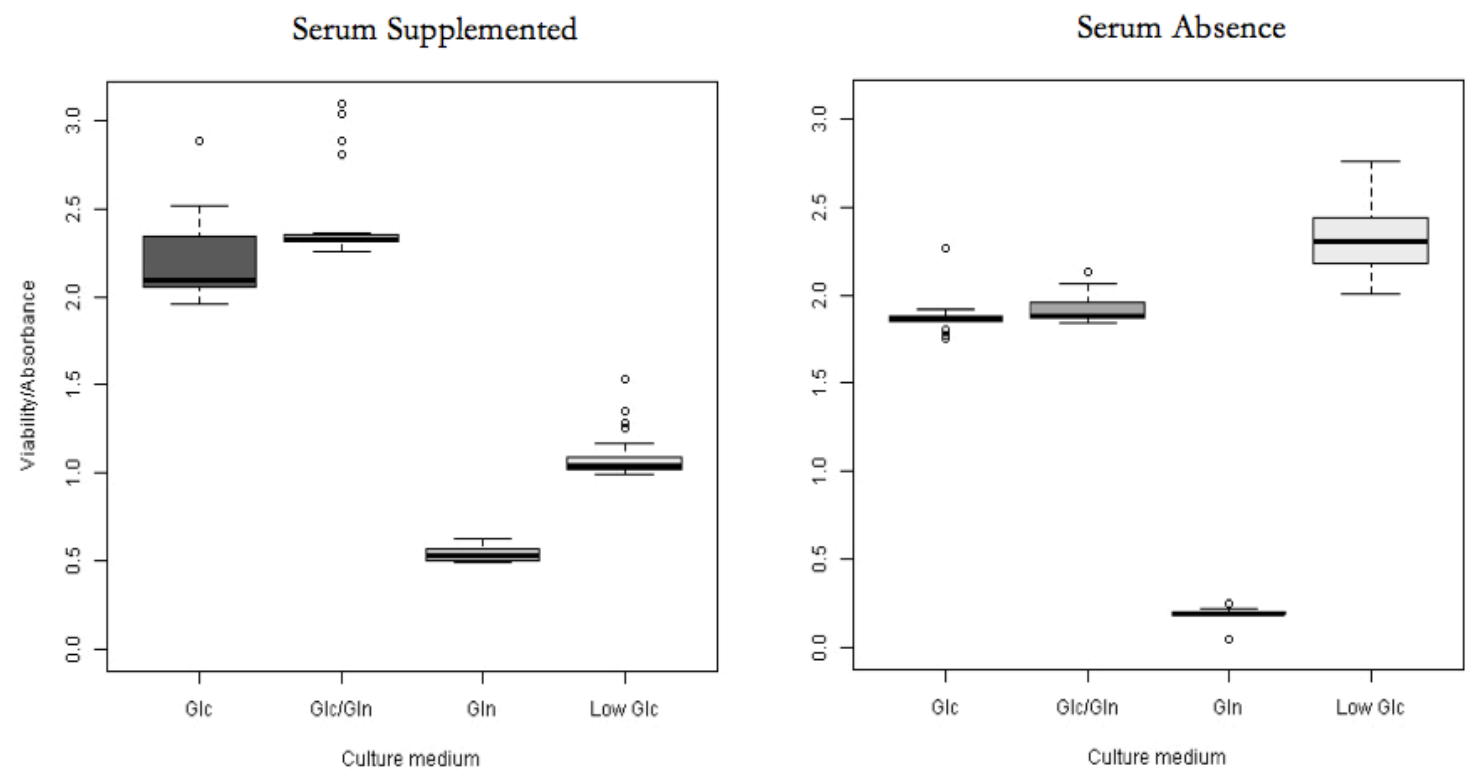

FIGURE 1 - Descriptive statistics of cell viability in serum supplemented and serum absence groups.

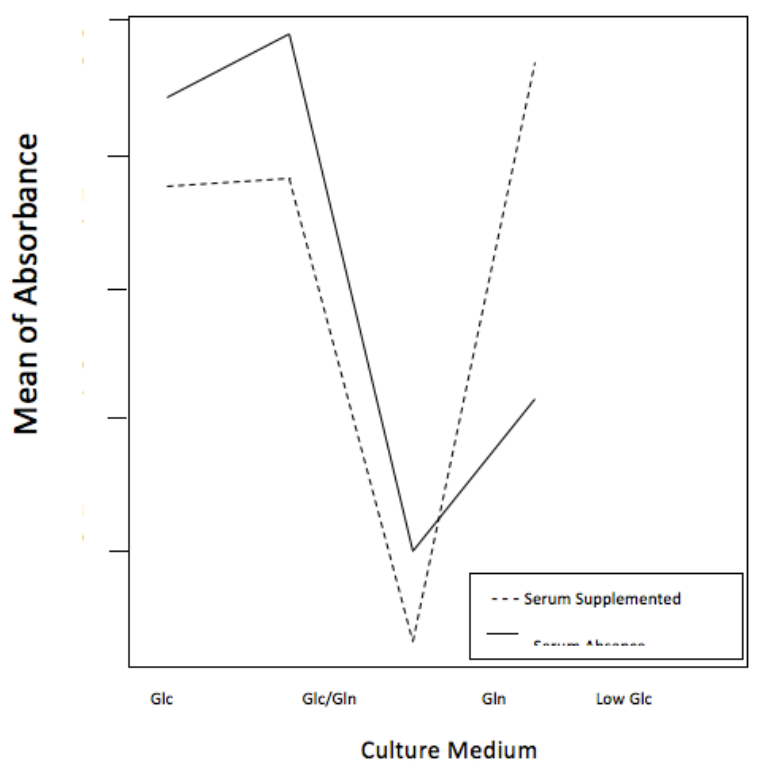

FIGURE 2 - Interaction between culture media and FBS by ANOVA statistical test.

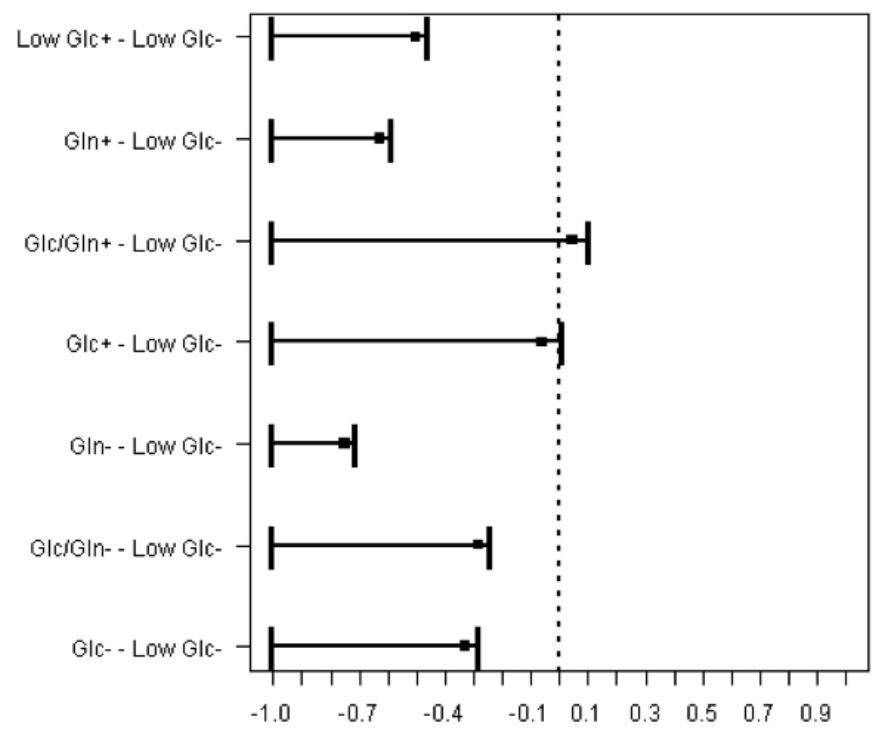

FIGURE 3 - Comparison of cell viability in Serum supplemented $(+)$ and Serum absence (-) groups using Low Glc serum absence as a reference. Non-parametric version of Dunnett's test. 
A chi-square test was applied to analyze the effect of culture media and FBS on the dead cells' number. The confidence interval strongly suggested that cell's death is affected exclusively by the culture medium $(\mathrm{p}<0.001)$ (Table 1$)$.

Although the Low Glc medium in serum absence illustrated a superior pattern of cell viability, we observed a

TABLE 1 - Confidence interval (95\%) for cell's death percentage, according to the serum supplemented and the serum absence culture medium groups.

\begin{tabular}{lcccccccc}
\hline Group & \multicolumn{2}{c}{ Glc } & \multicolumn{2}{c}{ Gln } & \multicolumn{2}{c}{ Glc/Gln } & \multicolumn{2}{c}{ Low Glc } \\
\hline $\begin{array}{l}\text { Serum } \\
\text { supplemented }\end{array}$ & 3.74 & 3.79 & 5.31 & 5.38 & 5.21 & 5.26 & 5.32 & 5.40 \\
$\begin{array}{l}\text { Serum } \\
\text { absence }\end{array}$ & 8.87 & 9.01 & 2.11 & 2.23 & 7.77 & 7.92 & 26.43 & 26.66 \\
\hline
\end{tabular}

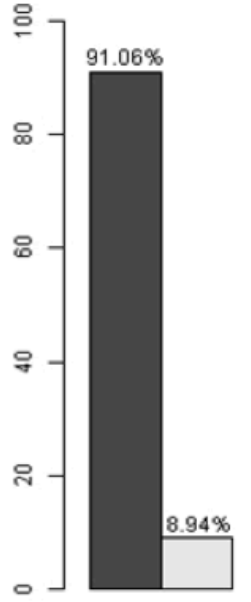

GIC

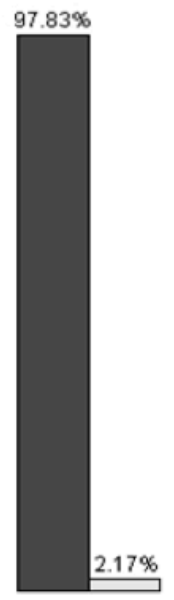

GIn

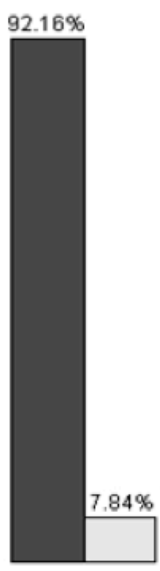

GIcjGIn

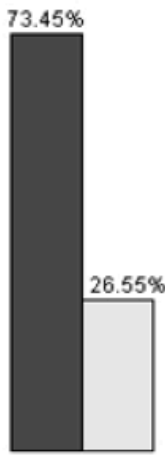

Low GIC
Culture

FIGURE 4 - Live and dead cells' percentages for all culture media in serum absence.

*Dark gray bars represent live cells; light gray bars, dead cells considerable number of dead cells. These results suggest a small group selection from a viable cell population. A statistically significant difference appeared among dead cells in all culture media studied $(\mathrm{p}<0.001)$ (Figure 4).

The serum supplemented culture medium decreased cell death percentage in all culture medium groups (Figure 5).

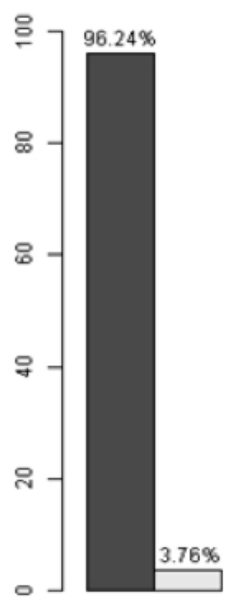

GIc

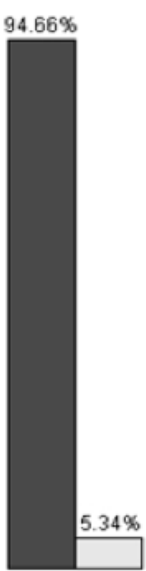

GIn

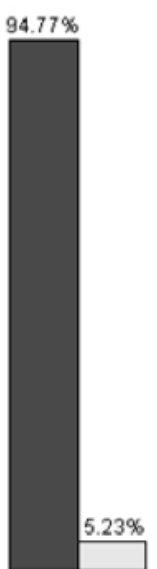

GIGIIn

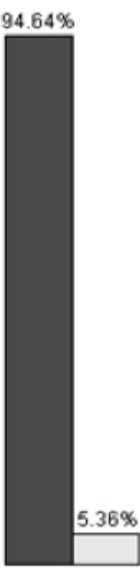

Low GIC
Culture

FIGURE 5 - Live and dead cells' percentages for all culture media in serum supplemented cells.

*Dark gray bars represent live cells; light gray bars, dead cells.

These data show the presence of non-characterized elements in FBS, affecting cell culture when associated with other nutrients. From a different perspective, nutrient flow alterations of glucose and glutamine modify the metabolic activity so as to induce direct effects on cell's death.

Microscopic evaluation of cell architecture denotes a misrepresented behavior in response to culture media composition, showing that FBS presence may induce transformations in the cellular morphology (Figure 6). 

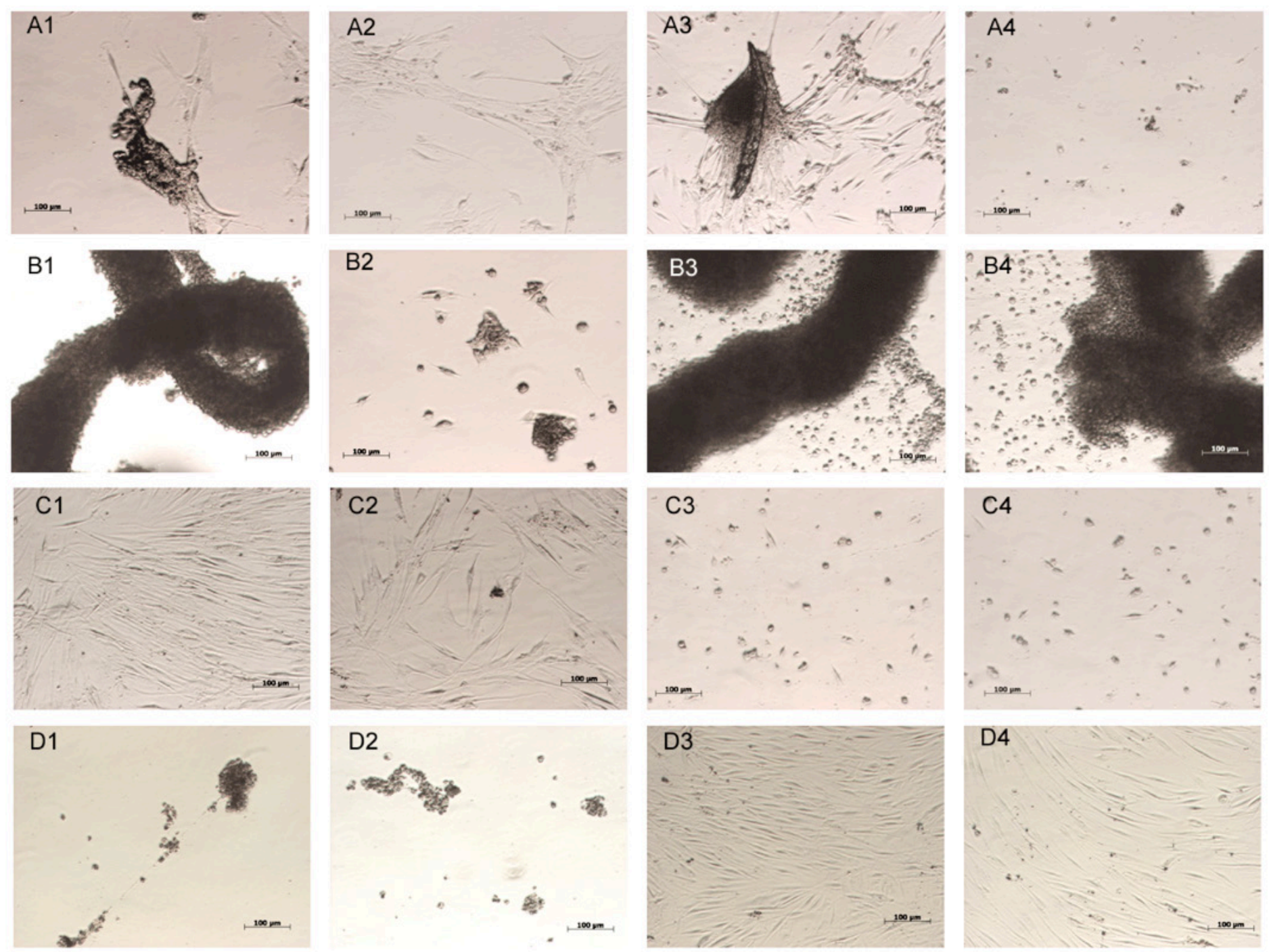

FIGURE 6 - Microscopic evaluation of cells under different concentrations of glucose and glutamine (scale bar $100 \mu \mathrm{m}$ ).

*Microscopic evaluation shows that the glucose excess in Glc culture medium (A) alters the cells' behavior both in serum supplemented (A1,A2) and serum absence $(\mathrm{A} 3, \mathrm{~A} 4)$ groups, damaging their configuration and adhesion. Gln culture medium promotes a disappearance process of the extracellular matrix in several phases, modifying the disposition of cells and forming amorphous and complexes structures in serum supplemented $(\mathrm{B} 1,2)$ and serum absence (B3,B4) groups. Alterations in the cells' arrangement were observed with discrete modifications in the serum absence group of Glc/Gln culture medium (C3,C4). Low doses of glucose in a serum-free culture medium favored the evolution of cells in this study, preserving their natural characteristics in the serum-free Low Glc culture medium (D3,D4). In contrast, FBS addition to this medium has induced the loss of extracellular matrix and the change in cells' form (D1,D2).

In both groups, serum supplemented $(1,2)$ and serum absence $(3,4)$ alterations were observed in conventional patterns of cell's behavior. The Glc culture medium displayed cell adherence discontinuity (A1-A3), showing a rounded shape, and cells partially detached, with small clusters were formed (A4).

Gln culture medium promoted extracellular matrix degradation in serum supplemented $(\mathrm{B} 1, \mathrm{~B} 2)$ and serum absence (B3,B4), adhesion damages, and unstable overlap of cells (B1,B3,B4). Hence, these complex and amorphous structures suggest a helpful role of glucose in extracellular matrix synthesis. Despite cytoskeleton rounding at some points of serum absence conditions $(\mathrm{C} 3, \mathrm{C} 4)$, cells' regular characteristics were maintained when serum was added to the Glc/Gln medium, keeping their adhesion and extracellular matrix $(\mathrm{C} 1, \mathrm{C} 2)$. Low Glc culture medium demonstrated supreme microscopic outline in serum absence, preserving the culture architecture, without signals of apoptosis or damage (D3, D4). In the serum supplemented group (D1, D2), important changes occurred, with total detachment of cells in culture, clusters formation, and cell rounding due to extracellular matrix absence.

Confocal microscopy did not demonstrated specific alterations in relation to nutrient concentrations in the circumstances of this study. Nevertheless, FBS promoted transformations in the cell structures studied here (Figure 7). Cytoskeleton presented significant structural damages and rounding, outside mitochondrial fragmentation and a discrete alteration in nucleus organization (A1, A2, A3). 

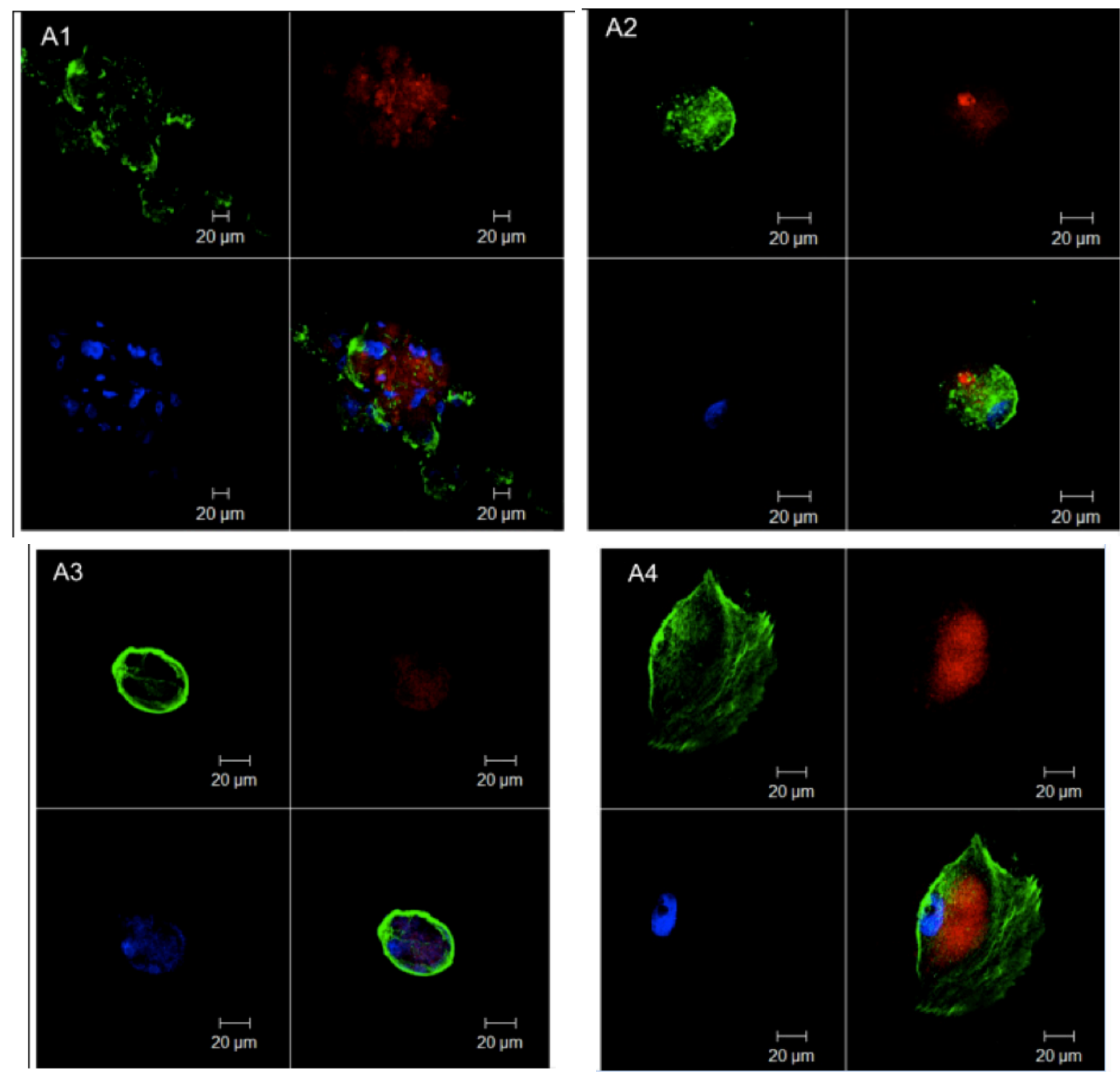

FIGURE 7 - Confocal microscopy in serum supplemented cells (scale bar $20 \mu \mathrm{m})$.

*The images show mitocondrial fragmentation and cytoskeleton rounding (A1-A3), besides destruction of adhesion and extracellular molecules (A1-A4).

The serum absence groups (Figure 8) also exhibited some structural impairment. However, this occurred in a smaller scale, preserving part of the classic configuration of the cellular structures.
Extensions of cytoskeleton were present, supporting cell adherence, cell to cell communication, and proliferation (B1, B2, $\mathrm{B} 3, \mathrm{~B} 4)$, despite eventual variations in the cytoskeleton contour (B1, B3). 

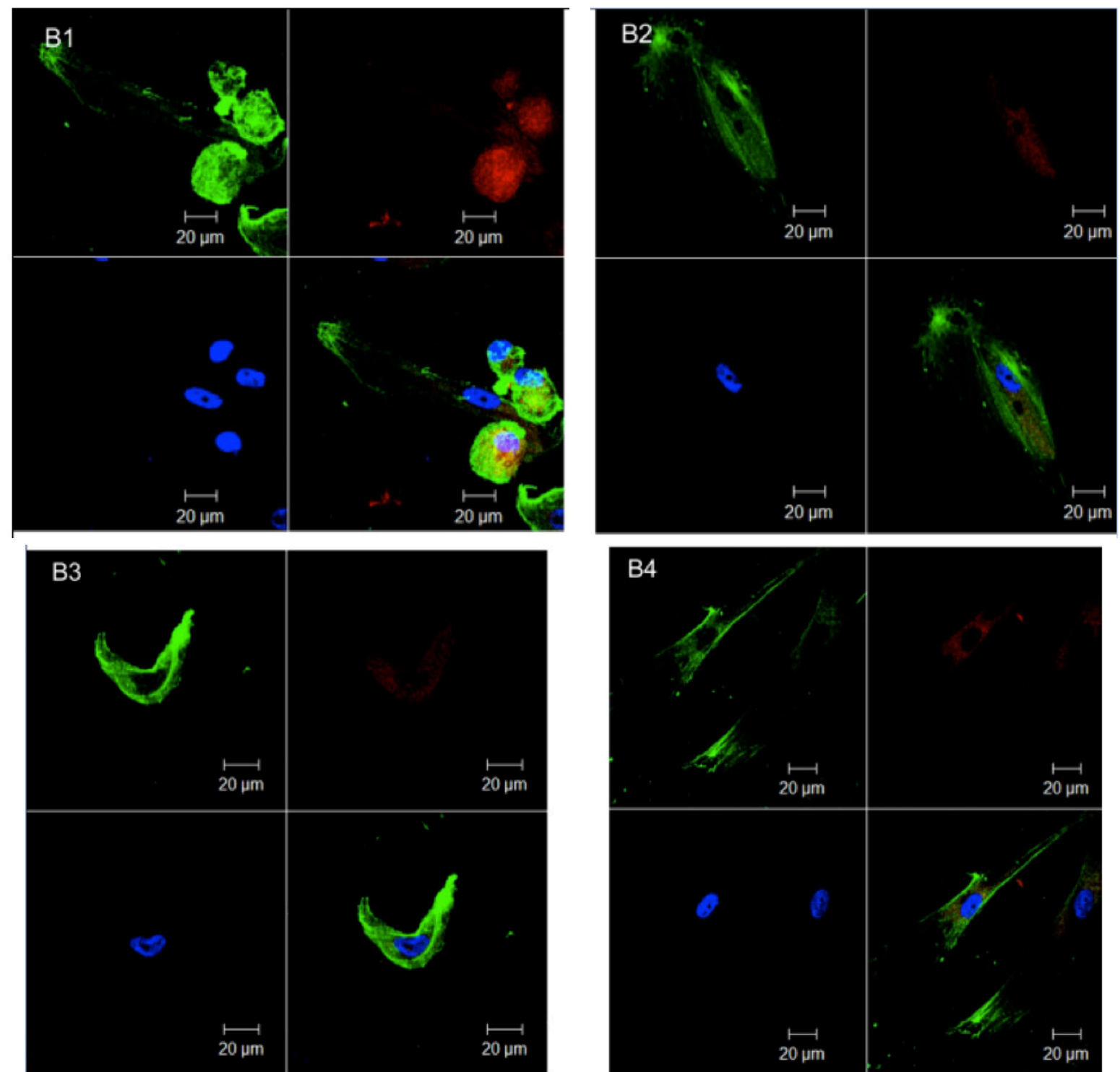

FIGURE 8 - Confocal microscopy in serum absence groups (scale bar $20 \mu \mathrm{m}$ ).

*Although serum absence illustrate some cell impairment, the extension of cytoskeleton as a sign of cell's adhesion is more present, even if variations occurred in their form (B1-B3).

\section{Discussion}

According to the established conditions and statistical tests performed in this study, it is possible to state that glucose and glutamine deprivation or their different concentrations promoted important alterations on cell behavior and viability. Certainly, additional tests are necessary to understand those transformations herein observed and to deepen the studies about the development of a serum-free culture medium that allows the cellular biological potential for cell transplantation in Regenerative Medicine use.

Microscopic analyses showed architecture alterations in cellular structures. These alterations include cell rounding and important reductions or absence of extracellular matrix molecules. Such transformations promoted an asymmetrical contour and cells' overlap, shifting essential interactions of cell-to-cell organization, invalidating proliferation and signaling, especially in glucose deprivation (Gln culture medium).

Modifications in extracellular matrix proteins might be a result of an inadequate energetic state, reflecting in tissue formation process due to lack in adherence and cell to cell signaling ${ }^{16}$. Although glucose has important properties as a central substrate of energy supply for biochemical reactions, several studies have described adverse effects of high concentrations. From the practical and experimental viewpoint, the commercialized high glucose culture media generally exhibit $4.500 \mathrm{mg} / \mathrm{L}$ of glucose, which corresponds to an in vivo $450 \mathrm{mg} / \mathrm{dL}$ glycemia while the low glucose culture medium with $1.000 \mathrm{mg} / \mathrm{L}$ corresponds to a $100.8 \mathrm{mg} / \mathrm{dL}$ glycemia $^{17}$. 
In the present study, low concentrations of this nutrient appear to be beneficial for maintaining cells' behavior and viability in vitro. Corroborating this information, a recent study also showed that the culture expansion under low glucose conditions preserved the desired characteristics for tissue formation ${ }^{18}$. Cell activity is modulated in accordance with its metabolic status, and this will interfere in the cell's biology and function, since the signal transduction, genetic expression, and metabolism depend on protein transformation processes ${ }^{19}$.

The DPSc glutamine requirements need more investigation. This nutrient is a non-essential amino acid because it can be synthesized from other amino acids. In the cell culture context, glutamine is considered as an important nutrient ${ }^{20}$, but it seems to contribute to cell culture only when associated with glucose.

Adequate submission of nutrients in cells' culture allows the organization of specific properties, contributing to the development of a dense cell population, preserving their morphology and natural viability. Occasionally, variations in nutrients concentrations and unwanted substances accumulation make up the cell culture context, interfering in the performance and expansion of cell's population. Moreover, the pattern of nutrient synthesis may vary according to culture conditions.

\section{Conclusion}

Cell's microscopic behavior and viability have demonstrated better patterns on serum-free low glucose culture medium with glutamine deprivation.

\section{References}

1. Duailibi SE, Duailibi MT, Zhang W, Asrican R, Vacanti JP, Yelick PC. Bioengineered dental tissues grown in the rat jaw. J Dent Res. 2008 Aug;87:745-50. PMID: 18650546.

2. Duailibi MT, Duailibi SE, Duailibi EF, Negreiros RM, Jorge WA, Ferreira LM, Vacanti JP, Yelick PC. Tooth tissue engineering: optimal dental stem cell harvest based on tooth development. Artif Organs. 2011 Jul;2(2):1-7. doi: 10.1111/j.1525-1594.2010.01200.x.

3. Batouli S, Miura M, Brahim J, Tsutsui TW, Fisher, Gronthos S, Robey PG, Shi S. Comparison of stem-cell-mediated osteogenesis and dentinogenesis. J Den Res. 2003 Dec;82:976-81. doi: $10.1177 / 154405910308201208$.

4. Bianco P, Robey PG, Simmons PJ. Mesenchymal stem cells: revisiting history, concepts, and assays. Cell Stem Cell. 2008 Apr;2:313-9. doi: 10.1016/j.stem.2008.03.002.

5. Vats A, Bielby RC, Tolley NS, Nerem R, Polak JM. Stem cells. Lancet. 2005 Aug;366:592-602. doi: 10.1016/S0140-6736(05)66879-1

6. Soto-Gutierrez A, Zhang L, Medberry C, Fukumitsu K, Faulk D, Jiang H, Reing J, Gramignoli R, Komori J, Ross M, Nagaya M, Lagasse E, Stolz D, Strom SC, Fox IJ, Badylak SF. A whole-organ regenerative medicine approach for liver replacement. Tissue
Eng Part C Methods. 2011 Jun;17(6):677-86. doi: 10.1089/ten. tec.2010.0698.

7. Bohnsack BL, Hirschi KK. Nutrient regulation of cell cycle progression. Ann Rev Nutr. 2004 Feb;24:433-53. doi: 10.1146/ annurev.nutr.23.011702.073203.

8. Metallo CM, Heiden MGV. Metabolism strikes back: metabolic flux regulates cell signaling. Genes Dev. 2010 Dec;24:2717-22. doi: 10.1101/gad.2010510

9. Wellen KE, Thompson CB. A two-way street: reciprocal regulation of metabolism and signalling. Nat Rev Mol Cell Biol. 2012 Mar;13:270-6. doi: 10.1038/nrm3305.

10. Deberardinis RJ, Thompson CB. Cellular metabolism and disease: what do metabolic outliers teach us? Cell. 2012 Mar;148:113244. doi: 10.1016/j.cell.2012.02.032.

11. Higera GA, Schop D, Spitters TW, Van Dijkhuizen-Radersma R, Bracke M, de Bruijn JD, Martens D, Karperien M, van Boxtel A, van Blitterswijk CA. Patterns of amino acid metabolism by proliferating human mesenchymal stem cells. Tissue Eng Part A. 2012 Mar;18(56):654-64. doi: 10.1089/ten.TEA.2011.0223.

12. Nakamura S, Yamada Y, Baba S, Kato H, Kogami H, Takao M, Matsumoto N, Ueda M. Culture medium study of human mesenchymal stem cells for practical use of tissue engineering and regenerative medicine. Biomed Mater Eng. 2008 Aug;18:129-36. doi:10.3233/BME-2008-0516.

13. Fulda S, Debatin KM. HIF-1-regulated glucose metabolism: a key to apoptosis resistance? Cell Cycle. 2007 Apr;6(7):790-2. doi: 10.4161/cc.6.7.4084.

14. Fuchs BC, Bode BP.Stressing out over survival: glutamine as an apoptotic modulator. J Surg Res. 2006 Mar; 131:26-40. doi: :10.1016/j.jss.2005.07.013.

15. Mosmann T. Rapid colorimetric assay for growth and survival application to proliferation and cytotoxicity assays. J Immunol Methods. 1983 Dec;65(1-2):55-63. doi: 10.1016/00221759(83)90303-4.

16. Ma Z, Wirström T, Borg LA, Larsson-Nyrén G, Hals I, Hansen JB, Grill V, Björklund A. Diabetes reduces $\beta$-cell mitochondria and induces distinct morphological abnormalities, which are reproducible by high glucose in vitro with attendant dysfunction. Islets. 2012 May-Jun; 4(3):233-42. doi: 10.4161/is1.20516.

17. Costa KD, Hucker WJ, Yin FC. Buckling of actin stress fibers: A new wrinkle in the cytoskeletal tapestry. Cell Motil Cytoskeleton. 2002 Aug;52(4):266-74. doi: 10.1002/cm.10056.

18. Heywood HK, Nalesso G, Lee DA, Dell'Accio F. Culture expansion in Low-Glucose conditions preserves chondrocyte differentiation and enhances their subsequent capacity to form cartilage tissue in three-dimensional culture. Bio Res. 2014 Feb;3(1):9-18. doi: 10.1089/biores.2013.0051.

19. Fock RA, Blatt SL, Beutler B, Pereira J, Tsujita M, de Barros FE, Borelli P. Study of lymphocyte subpopulations in bone marrow in a model of protein-energy malnutrition. Nutrition. 2010 Oct;26(10):1021-8. doi: 10.1016/j.nut.2009.08.026.

20. Eagle H. Nutrition needs of mammalian cells in tissue culture. Science. 1955 Sep;122(3168):501-4. PMID:13255879.

\section{Acknowledgements}

Plastic Surgery Department (UNIFESP), SED and MTD productivity scholarships (310048/2011-7 and 310049/2011-3), Instituto Nacional de Ciência e Tecnologia (INCT) - Biofabrication, Rede Biofab, Ibero-American Network of Biofabrication - BIOFABCYTED (208RT0340). We would also like to thank Liege Frainer Barbosa and André Frainer for assistance with manuscript editing. 


\section{Correspondence:}

Natasha Machado

Rua Mirassol, 207

04044-011 São Paulo - SP Brasil

Tel.: (55 11) 5084-8807

Fax: (55 11) 5084-8807

natashamachado@gmail.com

Received: May 21, 2014

Review: July 22, 2014

Accepted: Aug 20, 2014

Conflict of interest: none

Financial sources: Sao Paulo Research Foundation (FAPESP 2013/06877-

1) and National Council for Scientific and Technological Development (CNPq 5736661/2008-1)

${ }^{1}$ Research perfomed at Laboratory of Tissue Engineering and Biofabrication, Plastic Surgery Division, Surgery Department, Paulista School of Medicine, Federal University of Sao Paulo (EPM/UNIFESP), Brazil. Part of Master degree thesis, Postgraduate Program in Translational Surgery. Tutor: Prof. Silvio Eduardo Duailibi. 